\title{
PEMANFAATAN VISUAL ANIMASI SEBAGAI MEDIA INTERAKTIF UNTUK MENINGKATKAN MINAT BELAJAR
}

\author{
The Use Of Visual Animation As Interactive Media To Improve Learning Interest
}

\author{
Saprina Mamase ${ }^{1)}$, Frangky Tupamahu ${ }^{2)}$, Sri Ariyanti Sabiku ${ }^{3)}$ \\ ${ }^{1,2,3)}$ Staf Pengajar Program Studi Teknik Informatika
}

Jl. Muchlis Rahim Desa Panggulo, Kec. Botupingge Kab. Bone Bolango, Provinsi Gorontalo

E-mail : rina@poligon.ac.id ${ }^{1)}$

\begin{abstract}
ABSTRAK
Proses pembelajaran yang konvensional yaitu hanya dengan menggunakan papan tulis, buku teks dan metode ceramah kini mulai beralih dengan menggunakan media pembelajaran. Penggunaan media pembelajaran yang interaktif dapat mendukung terciptanya suasana proses pembelajaran yang menarik dan efektif, karena materi dapat divisualisasikan dengan bantuan media. Terdapat beragam media pembelajaran yang dapat digunakan oleh para guru untuk membuat rancangan bahan ajar. Namun ketersediaan media di sekolah masih terbatas dan kemampuan guru dalam mengembangkan media pembelajaran masih minim. Dengan demikian, dilakukan kegiatan pengabdian pada masyarakat berupa pelatihan pemanfaatan visual animasi sebagai media interaktif untuk meningkatkan minat belajar siswa. Pelatihan tersebut diberikan kepada guru-guru SMK Hidayatullah Kabupaten Pohuwato yang bertujuan untuk meningkatkan kemampuan guru dalam mengembangkan media pembelajaran berbasis animasi dengan menggunakan aplikasi sparkol. Kegiatan pelatihan melibatkan 13 orang guru SMK Hidayatullah. Pelatihan dilaksanakan dengan tahapan yaitu 1) Penyusunan materi pelatihan; 2) pemaparan materi tentang pentingnya media pembelajaran interaktif; 3) latihan dasar pengembangan media dengan sparkol; 4) sesi tanya jawab. Para guru begitu antusias mengikuti pelatihan ini, karena dengan adanya pelatihan ini dapat meningkatkan kemampuan guru dalam mengembangkan media pembelajaran.
\end{abstract}

Kata Kunci : media pembelajaran, sparkol, visual animasi

\begin{abstract}
Conventional learning methods such as those using whiteboard, text books, and traditional lecturing techniques are being replaced by the usage of learning media. The use of interactive leaning media could support attractive and effective learning, since the materials could be visualised using the help of media. There are several learning media which could be used by teachers to design learning materials. However, the availability of such media is still limited and the teachers' capability to develop the media could still be improved further.

Therefore, we conduct a community development program in the form of a training for teachers to use animated visual interactive media to improve students' learning interest. The training was given to teachers at SMK Hidayatullah in Pohuwato Regency which was aimed to improve the teachers' capability in developing animationbased learning media using sparkol application. The training was given to 13 SMK Hidayatullah's teachers. It was conducted in several stages, namely; 1) The development of training materials; 2) dissemination about the importance of interactive learning media; 3) media development training using sparkol; 4) question and answer session. The teachers were enthusiastic about the training, since it could improve their ability to develop learning media.
\end{abstract}

Keywords: learning media, sparkol, animated visual 


\section{PENDAHULUAN}

Media visual animasi merupakan suatu media pembelajaran yang dapat digunakan untuk meningkatkan minat belajar. Melalui media visual animasi, pemberi materi dapat menciptakan suatu pembelajaran yang menyenangkan, sehingga peserta didik dapat mengikuti dan memahami materi yang disampaikan dengan baik. Kehadiran teknologi media visual animasi memberi harapan baru dalam era pendidikan saat ini karena media pembelajaran ini mempunyai kegunaan yang tidak dimiliki oleh media lain sebelum ini. Media Visual animasi menampilkan informasi melalui suara, gambar, gerakan dan warna, baik secara alami maupun manipulasi. Materi pelajaran yang dikemas melalui program media, akan lebih jelas, lengkap, serta menarik minat siswa. Penggunaan media visual animasi dalam pembelajaran adalah suatu upaya untuk menciptakan suasana belajar kreatif dan inovatif tanpa mengurangi tujuan belajar yang sesungguhnya yaitu adanya perubahan tingkah laku siswa yang dapat diukur dan diamati. Menciptakan suasana belajar yang menarik bagi siswa tentulah hal yang ingin dicapai oleh guru dimanapun dan kapanpun juga. Dengan menarik perhatian siswa pada Kegiatan Belajar Mengajar, maka motivasi belajar siswa akan meningkat demikian pula pemahaman akan konsep materi pelajaran yang juga akan berdampak pada kualitas pembelajaran yang meningkat pula.

Tim pengabdian Prodi TI Poligon akan mengadakan pelatihan pemanfaatan Visual Animasi Sebagai Media Interaktif Untuk Meningkatkan Minat Belajar terutama pada sekolah-sekolah yang berlokasi jauh dari pusat kota. Kegiatan ini akan dilakasanakan di SMK Hidayatullah, Kabupaten Pohuwato. SMK Hidayatullah merupakan sekolah kejuruan swasta yang berdiri pada tahun 2014. SMK Hidayatullah memiliki 2 program kejuruan yaitu Rekayasa Perangkat Lunak dan Multimedia.

Pemanfaatan Media Visual animasi sebagai media interaktif ini diharapkan dapat meningkatkan minat belajar bagi siswa SMK Hidayatullah, Kabupaten Pohuwato. Berdasarkan hal tersebut diatas, sebagai bentuk implementasi salah satu Tri Dharma Perguruan Tinggi yaitu pengabdian terhadap masyarakat, maka Politeknik Gorontalo menyelenggarakan Pelatihan Pemanfaatan Media Viasual animasi sebagai Media Interaktif untuk meningkatkan minat belajar siswa di SMK Hidayatullah, Kabupaten Pohuwato.

\section{Permasalahan Mitra}

Meningkatkan kualitas hasil belajar dari para siswa-siswi SMK Hidayatullah Marisa melalui media visual animasi dalam proses kegiatan belajar mengajar. Penggunaan media bukan hanya membuat proses pembelajaran lebih efisien, tetapi juga membantu siswa menyerap materi pelajaran lebih mendalam dan utuh. Bila hanya dengan mendengarkan informasi verbal dari guru saja, siswa mungkin kurang memahami pelajaran secara baik. Tetapi jika hal itu diperkaya dengan proses kegiatan belajar mengajar yang interaktif melalui media, maka pemahaman siswa pasti akan lebih baik. Sehingga Tim pengabdian Prodi TI perlu mengadakan kegiatan pelatihan pemanfaatan Visual Animasi Sebagai Media Interaktif untuk meningkatkan minat belajar di SMK Hidayatullah Marisa, Kabupaten Pohuwato, Provinsi Gorontalo.

\section{SOLUSI DAN TARGET LUARAN}

\section{a. Solusi dan tujuan}

Secara terperinci tujuan yang dicapai dalam kegiatan pelatihan pemanfaatan Visual Animasi Sebagai Media Interaktif untuk meningkatkan minat belajar adalah: 
1. Proses belajar menjadi lebih interaktif. Jika dipilih dan dirancang secara baik, media dapat membantu guru dan siswa melakukan komunikasi dua arah secara aktif selama proses pembelajaran. Tanpa media, seorang guru mungkin akan cenderung berbicara satu arah kepada siswa. Namun dengan media, guru dapat mengatur kelas sehingga bukan hanya guru sendiri yang aktif tetapi juga siswanya.

2. Efesiensi dalam waktu dan tenaga. Keluhan yang selama ini sering kita dengar dari guru adalah, selalu kekurangan waktu untuk mencapai target kurikulum. Sering terjadi guru menghabiskan banyak waktu untuk menjelaskan suatu materi pelajaran. Hal ini sebenarnya tidak harus terjadi jika guru dapat memanfaatkan media secara maksimal. Misalnya, tanpa media seorang guru tentu saja akan menghabiskan banyak waktu untuk mejelaskan sistem peredaran darah manusia atau proses terjadinya gerhana matahari. Padahal dengan bantuan media visual, topik ini dengan cepat dan mudah dijelaskan kepada anak. Biarkanlah media menyajikan materi pelajaran yang memang sulit untuk disajikan oleh guru secara verbal. Dengan media, tujuan belajar akan lebih mudah tercapai secara maksimal dengan waktu dan tenaga seminimal mungkin. Dengan media, guru tidak harus menjelaskan materi pelajaran secara berulang ulang, sebab hanya dengan sekali sajian menggunakan media, siswa akan lebih mudah memahami pelajaran.

\section{b. Target Luaran}

Jenis Luaran Kegiatan :

1. Publikasi Jurnal berISSN
2. Peningkatan kemampuan guru dalam membuat media pembelajaran interaktif berbasis animasi

\section{METODE PELAKSANAAN KEGIATAN}

Media belajar sangat membantu dan menarik dalam proses belajar mengajar, karena media dapat dipergunakan untuk memperbesar yang kecil dan mengecilkan yang besar, menyederhanakan yang kompleks, mempercepat proses atau memperlambat proses dan sebagainya. Lebih jauh lagi media belajar membuat pendidikan berdaya mampu tinggi, produktif, serempak, merata, aktual dan menarik[1]. Multimedia Interaktif merupakan alat atau sarana pembelajaran yang berisi materi, metode, batasan-batasan, dan cara mengevaluasi yang dirancang secara sistematis dan menarik untuk mencapai kompetensi/subkompetensi mata pelajaran yang diharapkan sesuai dengan tingkat kompleksitasnya[2].

Penggunaan media pembelajaran secara interaktif telah banyak dilakukan oleh para peneliti, dianataranya adalah penerapan media animasi yang dalam penelitian tersebut yang dilakukan bertujuan dalam meningkatkan minat belajar peserta didik kelas XI SMA PGII2 Bandung[3]. Sama halnya dengan penelitian dari (Venessa Agusta dkk, 2018) yang membahas tentang penggunaan multimedia interaktif sebagai bahan penunjang media presentasi[4]. Penelitian ini berfokus pada sumber daya manusia mabes polri Jakarta selatan untuk menambah kreatifitas anggota mabes polri dalam mempersiapkan materi presentasi. Multimedia penunjang dalam sebuah presentasi bisa dibuat dengan menggunakan berbagai cara diantaranya dengan menggunakan adobe photoshop untuk mengubah gambar atau adobe 
premier untuk menyatukan potongan video menjadi sebuah video yang utuh. Multimedia interaktf diharapkan bisa menjadi penunjang yang baik dalam sebuah presentasi.

Untuk meningkatkan minat belajar di Lingkungan SMK Hidayatullah, maka Tim pengabdi akan memberikan pelatihan pemanfaatan visual media sebagai media interaktif kepada siswa - siswa SMK Hidayatullah. Adapun visual media yang digunakan adalah Sparkol VideoScribe. Metodologi kegiatan yang akan dilakukan dalam kegiatan pengabdian kepada masyarakat dalam penerapan visual media animasi senagai media interaktif dalam proses belajar mengajar antara lain :

1. Pembuatan Modul Materi media Visual menggunakan Aplikasi Sparkol Videoscrabe

2. Datang berkunjung ke SMK dan memberikan pelatihan tentang pemanfaatan media visual sebagai media interaktif untuk meningkatkan minat belajar

3. Monitoring dan evaluasi pemahaman dalam penggunaan visual media animasi

4. Menyusun laporan akhir program kemitraan masyarakat untuk dipertanggungjawabkan kepada Politeknik Gorontalo

Adapun tempat dan waktu Pelaksanaan kegiatan yaitu bertempat di SMK Hidayatullah, Kabupaten Pohuwato, Jumat-Sabtu, 13-14 September 2019

\section{HASIL DAN PEMBAHASAN}

Pelaksanaan kegiatan Pengabdian kepada Masyarakat "Pemanfaatan Visual Animasi Sebagai Media Interaktif Untuk Meningkatkan Minat Belajar" melibatkan 13 guru di SMK Hidayatullah, Kabupaten
Pohuwato. Uraian pelaksanaan masingmasing sub kegiatan dapat diuraikan sebagai berikut :

1. Penyusunan materi pelatihan

Tim pengabdian menyusun analisis kebutuhan terhadap materi pelatihan yang akan diberikan kepada peserta. Materi pelatihan yang disusun berjudul "Pemanfaatan aplikasi Sparkol sebagai media pembelajaran interaktif berbasis animas". Penyusunan materi dilaksanakan mulai tanggal 27 Agustus 2019 hingga 3 September 2019. Materi disusun dalam tiga bagian yaitu 1) Pengantar media pembelajaran, 2) Materi tentang pentingnya media pembelajaran interaktif berbasis animasi, 3) Pengenalan aplikasi Sparkol, dan 4) cara menggunankan aplikasi sparkol dalam menyusun bahan ajar.

2. Pelatihan Pembuatan Media Pemebalajaran berbasis animasi menggunakan aplikasi sparkol.

Kegiatan dilaksanakan pada hari Jumat dan Sabtu, tanggal 13 s.d 14 September 2019 pukul 09.00- 16.00 Wita yang dihadiri oleh 20 guru SMK Hidayatullah Kab. Pohuwato. Kegiatan dilaksanakan di salah satu ruang kelas SMK Hidayatullah Kabupaten Pohuwato.

Pemaparan materi $\begin{array}{r}\text { diawali } \\ \text { dengan penyampaian }\end{array}$
tentang
pentingnya pemanfaatan media
pembelajaran interaktif berbasis
animasi yang dapat meningkatkan
minat belajar para siswa. Oleh
karenanya ketersediaan media
pembelajaran baik konkrit maupun
berbasis komputer terpenuhi. Guru
juga harus kreatif dalam
mengembangkan medianya sendiri.
Setelah diberikan penyadaran tentang
pentingnya media, dilanjutkan dengan
simulasi penggunaan media baik media


konkrit maupun media berbasis komputer.

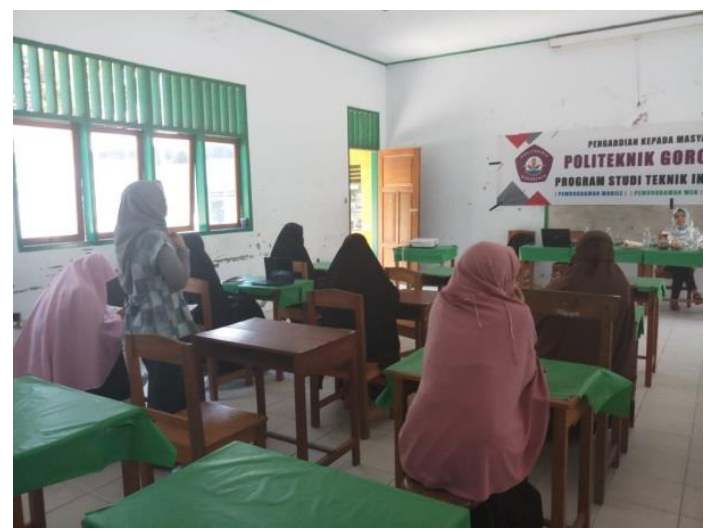

Gambar 1. Penyampaian Pentingnya

Pemanfaatan media pembelajaran interaktif

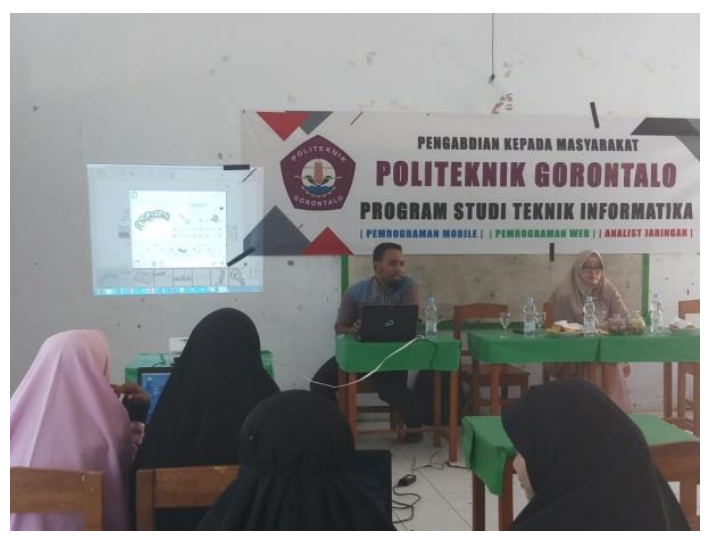

Gambar 2. Penyampaian Materi Media Pembelajaran Berbasis Animasi

Selanjutnya, pengenalan tools pada aplikasi sparkol yang merupakan salah satu aplikasi berbasis animasi yang dapat digunakan sebagai media pembelajaran. Setelah para guru memahami berbagai tools yang ada pada sparkol, kegiatan berikutnya adalah demo pembuatan bahan ajar menggunakan aplikasi sparkol.

3. Sesi tanya jawab

Pada kegiatan ini, para peserta mencoba dan mempraktekkan langsung aplikasi sparkol dalam pembuatan video animasi yang sederhana untuk persiapan merancang media pembelajaran interktif berbasis animasi. Selanjutnya peserta diperkenankan untuk memberikan pertanyaan yang berkaitan dengan penggunaan tools yang apa pada aplikasi sparkol.

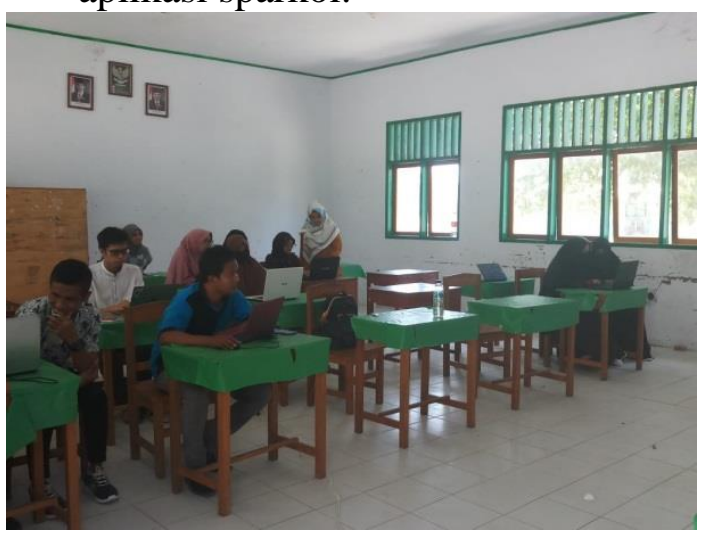

Gambar 3. Kegiatan Sesi Tanya Jawab

Pada sesi, ini tim pengabdian datang langung ke tempat para guru untuk melihat/mengevaluasi pengetahuan para guru terkait penggunaan aplikasi sparkol. Para guru juga begitu antusias mengikuti praktikum ini dan begitu banyak pertanyaan yang muncul dari para guru terkait penggunaan aplikasi sparkol tersebut.

4. Penutup

Kegiatan pelaksanaan pelatihan pembuatan media pembelajaran interaktif berbasis animasi menggunakan sparkol berakhir pada hari Sabtu, 14 September 2019.

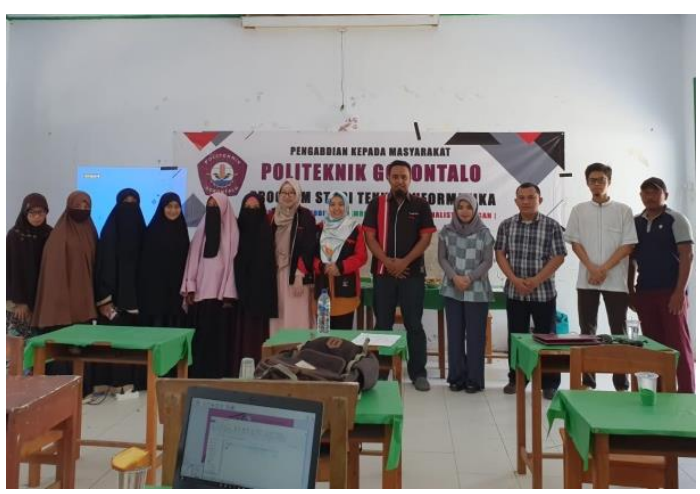


Acara Penutup dengan Foto Bersama Peserta

\section{EVALUASI}

Seluruh peserta pelatihan sebanyak 13 orang telah mengetahui penggunaan berbagai macam tools dalam aplikasi sparkol dan juga mengimplemtasikannya. Dari 13 orang, telah ada $6(50 \%)$ orang yang telah menindaklanjuti pelatihan dengan berhasil mengembangkan media. Keenam produk tersebut selanjutnya nilai dengan memberikan skor skala tiga (skor 1: tidak baik, skor 2:baik, skor 3: sangat baik) terhadap 3 aspek penilaian dengan rekapan seperti Tabel 1 berikut.

Tabel 1. Hasil Penilaian Produk Media

\begin{tabular}{|c|c|c|c|c|c|c|c|}
\hline \multirow[t]{2}{*}{$\begin{array}{l}\mathbf{N} \\
\mathbf{0}\end{array}$} & \multirow{2}{*}{$\begin{array}{l}\begin{array}{l}\text { Aspek } \\
\text { Penilaian }\end{array} \\
\text { Aspek Isi }\end{array}$} & \multicolumn{6}{|c|}{ Produk } \\
\hline & & 1 & 2 & 3 & 4 & 5 & 6 \\
\hline 1 & $\begin{array}{l}\text { Kesesuaian } \\
\text { dengan } \\
\text { kurikulum }\end{array}$ & 2 & 2 & 3 & 2 & 3 & 3 \\
\hline \multirow[t]{2}{*}{2} & $\begin{array}{lr}\text { Materi } & \text { yang } \\
\text { disajikan } & \text { pada } \\
\text { media } & \text { sudah } \\
\text { benar } & \text { dan } \\
\text { akurat } & \\
\end{array}$ & 3 & 3 & 3 & 2 & 2 & 2 \\
\hline & $\begin{array}{l}\text { Aspek } \\
\text { Tampilan }\end{array}$ & & & & & & \\
\hline 3 & $\begin{array}{l}\text { Tampilan } \\
\text { media menarik }\end{array}$ & 3 & 3 & 2 & 2 & 3 & 2 \\
\hline \multirow[t]{2}{*}{4} & $\begin{array}{l}\text { Media } \\
\text { memungkinka } \\
\mathrm{n} \text { siswa terlibat } \\
\text { aktif dalam } \\
\text { penggunaanny } \\
\text { a } \\
\end{array}$ & 2 & 3 & 3 & 2 & 2 & 2 \\
\hline & Aspek Bahasa & & & & & & \\
\hline \multirow[t]{2}{*}{5} & $\begin{array}{l}\text { Bahasa efektif } \\
\text { dan efisien }\end{array}$ & 2 & 3 & 3 & 2 & 3 & 3 \\
\hline & Rata-rata & $\begin{array}{l}2 . \\
4\end{array}$ & $\begin{array}{l}2 . \\
8\end{array}$ & $\begin{array}{l}2 . \\
8\end{array}$ & 2 & $\begin{array}{l}2 . \\
6\end{array}$ & $\begin{array}{l}2 . \\
4\end{array}$ \\
\hline
\end{tabular}

(diadopsi dari Waryanto, 2008)
Kualitas media dapat dilihat dari rata-rata skornya yang selanjutnya dikonversi menjadi 3 kategori sesuai Tabel 2 berikut.

Tabel 2. Kriteria Kualitas Media

\begin{tabular}{|l|l|}
\hline Rata-Rata Skor & Kriteria \\
\hline $2.36 \leq \mathrm{X}<3.00$ & Baik \\
\hline $1.68 \leq \mathrm{X}<2.36$ & Cukup Baik \\
\hline $1 \leq \mathrm{X}<1.68$ & Tidak Baik \\
\hline
\end{tabular}

(dimodifikasi dari Beni, Gita, \& Suarsana, 2017)

\section{KESIMPULAN}

Beberapa hal yang dapat disimpulkan dari hasil kegiatan pengabdian ini dianataranya (1) guru-guru SMK Integral Hidayahtullah Kabupaten Pohuwato telah menyadari pentingnya keberadaan media interaktif berbasis animasi dalam pembelajaran yang lebih menarik, (2) sebagaian guru-guru telah mampu menggunakan aplikasi sparkol dalam membuat media pembelajaran yang interaktif, (3) kualitas media yang dihasilkan guru sebagaian diantaranya sudah berkualitas baik.

\section{DAFTAR PUSTAKA}

[1] Rokhman, M. Nur, Murdyastomo, and HY. Agus, "Pembuatan Media Slide Suara Untuk Mata Pelajaran Sejarah SMU," $J$. Inov. Dan Apl. Teknol., vol. 9, no. 1, 2005.

[2] A. Candrana, A. Mulyana, and T. A. Riza, "Aplikasi Sistem Informasi Penjualan Makanan Khas Kota Jember Berbasis Web Pada Toko Hamdalah," 2012.

[3] M. Nazmi, "Penerapan Media Animasi Untuk Meningkatkan Minat Belajar Peserta Didik Pada Mata Pelajaran Geografi Di SMA PGII 2 Bandung," J. Pendidik. Geogr., vol. 17, no. 1, pp. 48-57, 2017.

[4] V. A. Gogali, C. Y. Erlangga, and J. P. Putra, "Penggunaan Multimedia Interaktif Sebagai Bahan Penunjang Media Presentasi ( Studi pada SSDM Mabes Polri Jakarta Selatan )," J. ABDIMAS BSI, vol. 1, no. 3, pp. 503-509, 2018.

[5] Waryanto, N. H, "Evaluasi Multimedia Interaktif,"Yogyakarta: Universitas 
Pendidikan Ganesha, 2008.

[6] Beni, K., Gita, I. N., and Suarsana, I. M, "Media Pembelajaran Matematika Interaktif untuk Siswa Tunarungu: Perancangan dan Validasi," Seminar Nasional Pendidikan Teknik Informatika Senapati, pp. 16-22, 2017. 